\title{
Harnessing REDD+ opportunities for forest conservation and carbon stock enhancement in the Northeastern States of India
}

\author{
Indu K. Murthy ${ }^{1}$, Nitasha Sharma ${ }^{1,2}$, Ravindranath Nijavalli $\mathbf{H}^{1}$ \\ ${ }^{1}$ Centre for Sustainable Technologies, Indian Institute of Science, Bangalore, India; indukmurthy@gmail.com \\ ${ }^{2}$ Indiana University, Bloomington, USA
}

Received 30 November 2012; Revised 30 December 2012; accepted 14 January 2013

\section{ABSTRACT}

Forests have significant economic and ecological value as a provider of ecosystem services, being home to much of the world's biodiversity and supporting the livelihoods of many people. Reducing emissions from deforestation and forest degradation in developing countries (REDD) is a critical component of the overall greenhouse gas emission reductions and now the significance of REDD+ (which is not only about reducing emissions but halting and reversing forest loss), in delivering climate change mitigation benefits along with co-benefits, is increasingly being recognized in global climate negotiations. Northeast India provides a tremendous potential for harnessing REDD+ activities with about $66 \%$ of the total geographical area of the region being covered by forests. This paper attempts to explore this potential besides estimating the area available for different options under REDD+ as well as the mitigation potential using COMAP model, overcoming limitations of existing studies or a lack of them. Within this, the status of forests and biodiversity along with drivers of deforestation in north east India are documented and an assessment of the potential for taking up reducing deforestation and degradation and enhancement of carbon stocks and afforestation is conducted both at the state as well as district level. It was found that northeastern states have been experiencing net forest loss during the last few years along with significant scale forest degradation, with Nagaland followed by Arunachal Pradesh offering maximum potential for "reducing deforestation" option under REDD and the total incremental annual mitigation potential of the four REDD+ activities in northeast India being $29.2 \mathrm{MtCO}_{2}$ for 2030.
Keywords: Forests; Climate Change; REDD+; Mitigation Potential; Northeast India

\section{INTRODUCTION}

Emissions from the forest sector, are estimated to be in the range of 0.5 to $2.7 \mathrm{GtC}$ (Giga tonnes of Carbon) during the $1990 \mathrm{~s}$, with a mean of about $1.6 \mathrm{GtC}$. The rapid destruction of tropical forests produces $\sim 20 \%$ of anthropogenic carbon emissions, which fuels climate change and poses one of the greatest perils to global biodiversity [1], 2008. According to the IPCC, the mitigation potential of forest sector is estimated to be in the range of 8.2 to $13.5 \%$ of total mitigation potential, considering all sectors. Forests can also contribute to climate change mitigation [2] in four ways 1) increase in forest area through reforestation; 2) increase in carbon density of existing forests at both stand and landscape scales; 3) sustainably manage forests for harvesting forest products; and 4) reduce emissions from deforestation and degradation.

The potential of the last activity has already been recognized in global climate negotiations by means of REDD or Reducing Emissions from Deforestation and forest Degradation. The other three activities are also now a part of what is called REDD+. The Bali Action Plan recognized the importance of REDD and additional activities that includes "reducing emissions from deforestation and forest degradation in developing countries, and the role of conservation, sustainable management of forests and enhancement of forest carbon stocks in developing countries". REDD is an important component of the Copenhagen Accord too and it recognizes the need for positive incentives for REDD with significant financial commitment.

The 2007 Bali Climate Change Conference initiated studies into the provision of financial compensation for developing countries for the loss of revenue resulting from forest protection. There has been broad consensus 
that the REDD approach, should be a prominent feature of any international climate change agreement that replaces the Kyoto Protocol in 2012. After almost three years of difficult negotiations, parties to the UN Framework Convention on Climate Change (UNFCCC) have agreed to slow, halt, and reverse forest loss and the related emissions in developing countries (REDD+). The Cancun Agreement clearly states that REDD+ is not only about reducing emissions but halting and reversing forest loss. This is important as it emphasizes that REDD+ actions must result in maintaining existing forests and enhancing carbon stocks. Second, the agreement encourages all countries to find effective ways to reduce the anthropogenic pressures on forests that result in greenhouse gas emissions. Though this agreement represents a step towards a fully-fledged REDD+ framework, there are important questions left unanswered. These include creating a REDD goal, nature of financing, scale of the project (national and sub-national), links to NAMAs (Nationally Appropriate Mitigation Actions) and GHG (Greenhouse Gas) emission strategies and MRV (Monitoring, Reporting and Verification). There is however general agreement on the safeguards (rights of local communities), addressing drivers of deforestation and forest degradation, methodology for monitoring carbon benefits and linking REDD+ with sustainable development and poverty reduction.

With this background, we explore the potential for harnessing REDD+ opportunities for reducing deforestation and degradation, forest conservation and enhancement of carbon stocks in northeast India.

\section{THE NORTHEAST INDIA}

The Northeast India comprises the 8 states-Arunachal Pradesh, Assam, Manipur, Meghalaya, Mizoram, Nagaland, Tripura and Sikkim extending over an area of $262,000 \mathrm{~km}^{2}$ and accounting for $7.9 \%$ of the total geographical area of the country. The Siliguri Corridor in West Bengal, with an average width of $21 \mathrm{~km}$ to $40 \mathrm{~km}$, connects the northeastern region with mainland India.
More than $2000 \mathrm{~km}$ of the boundary of this region is shared with other countries, namely, Nepal, China, Bhutan, Myanmar and Bangladesh. The northeastern region can be divided into the Eastern Himalayas, the northeastern Hills and the River Valley Plains. Table 1 describes the land-use pattern of the northeastern states.

\subsection{Status of Forests in the Northeast States}

On the basis of legal status, the forests of the northeastern region can be classified as Reserve Forest, Protected Forest and Unclassed Forest. The Reserve Forests are constituted under the Indian Forest Act, 1927 and the State Forest Act and are accorded complete protection under the law. The protected forests are constituted under Chapter 4 of the Indian Forest Act and have limited degree of protection. Unclassed forests are those forests that are neither included under Reserve nor the Protected Forest categories and the tenurial or ownership status of this forest category varies across the northeastern states.

According to the Forest Survey of India [4], about $66 \%$ of the total geographical area of the Northeastern region is covered by forests although there are inter-state variations. Table 2 shows the state-wise forest area (recorded and actual) as per the State of Forest Report 2009. The percentage forest area to the total geographic area is highest in Mizoram (91.3\%) followed by Nagaland and Arunachal Pradesh with more than $80 \%$ area under forests. Manipur, Meghalaya and Tripura have about $77 \%$ of the total geographic area under forests. The percentage forest area to the total geographic area is lowest in Sik$\operatorname{kim}(47.3 \%)$ and Assam (35.3\%).

The total forest cover in the region is $17.04 \mathrm{Mha}$, which is $66.8 \%$ of the total geographic area as against a national average of $21.02 \%$. Very dense forests constitute $9.7 \%$ while moderately dense and open forests constitute $29 \%$ and $28 \%$ of the total forest cover of the region, respectively. In most of the hilly northeastern states, indigenous community institutions play an important role in forest protection, management and administration and

Table 1. Land-use pattern ('000 ha) of the Northeast states (2006-2007).

\begin{tabular}{|c|c|c|c|c|c|c|c|c|}
\hline \multirow{2}{*}{ Land-use categories } & \multicolumn{8}{|c|}{ States } \\
\hline & Arunachal & Assam & Manipur & Meghalaya & Mizoram & Nagaland & Tripura & Sikkim \\
\hline Total geographical area & 8374 & 7844 & 2233 & 2243 & 2108 & 1658 & 1049 & 710 \\
\hline Total cropped area & 275 & 3553 & 224 & 265 & 92 & 406 & 294 & 123 \\
\hline Area under forests & 5659 & 1954 & 1693 & 942 & 1594 & 863 & 606 & 319 \\
\hline Land not available for cultivation & 65 & 2512 & 27 & 228 & 134 & 75 & 134 & 250 \\
\hline Uncultivated land excluding fallow land* & 122 & 445 & 8 & 608 & 21 & 177 & 28 & 12 \\
\hline Fallow land other than current fallow & 73 & 60 & 0 & 169 & 82 & 76 & 1 & 30 \\
\hline Current fallow & 37 & 127 & 0 & 68 & 24 & 82 & 1 & 5 \\
\hline
\end{tabular}

*Includes permanent pastures and other grazing lands Source: [3]. 
Table 2. State-wise forest cover ('000 ha) in the Northeastern states in 2007.

\begin{tabular}{ccccccc}
\hline State & Geographical area & Very dense forest & Moderately dense forest & Open forest & Total & \% of geographic area \\
\hline Arunachal Pradesh & 8374.3 & 2085.8 & 3155.6 & 1493.9 & 6735.3 & 8.043 \\
Assam & 7843.8 & 146.1 & 1155.8 & 1467.3 & 2769.2 & 3.53 \\
Manipur & 2232.7 & 70.1 & 547.4 & 1110.5 & 1728 & 7.74 \\
Meghalaya & 2242.9 & 41 & 950.1 & 741 & 1732.1 & 7.723 \\
Mizoram & 2108.1 & 13.4 & 625.1 & 1285.5 & 1924 & 9.127 \\
Nagaland & 1657.9 & 127.4 & 489.7 & 729.3 & 1346.4 & 8.121 \\
Sikkim & 709.6 & 50 & 216.1 & 69.6 & 335.7 & 4.731 \\
Tripura & 1048.6 & 11.1 & 477 & 319.2 & 807.3 & 7.695 \\
Total & 25508.3 & 2494.9 & 7400.7 & 7146.7 & 17042.3 & 6.681 \\
\hline
\end{tabular}

Source: State of Forest Report 2009, Forest Survey of India.

the livelihoods of these communities are heavily dependent upon these forests. Involvement of indigenous people in the decision making process is thus, an important pre-requisite for implementing REDD + activities in northeast. Forests of northeast India also face unrelenting pressures resulting in degradation and deforestation $[5,6]$.

\subsection{Biodiversity}

The Northeast India is a part of two global biodiversity hotspots namely, Himalaya and Indo-Burma. The region contains more than one-third of the country's total biodiversity. The estimate of the species biodiversity of Northeast India reported so far includes 7500 species of plants including 700 species of orchids, 64 species of citrus, 28 species of conifers, 58 species of bamboos, 700 species of ferns, 500 species of mosses, etc. about 3624 species of insects, 50 mollusks, 236 species of fish, 541 types of birds, 160 species of mammals, 64 species of amphibians, and 137 species of reptiles [7]. The ecosystem diversity of the region ranges from tropical ecosystems to alpine ecosystems in the Himalayan ranges and also includes wetlands, flood plains, riverines and aquatic ecosystems. Deforestation, shifting cultivation, forest land encroachment, grazing, human wildlife conflict, forest fires, illegal extraction of forest products, increasing commercial plantations, uncoordinated infrastructure development, mining and construction of mega dams are considered as some of the threats to biodiversity in this region.

\section{REDD+ IN THE CONTEXT OF NORTHEASTERN INDIA}

The northeastern region is very rich in forest resources. The region is rich in biodiversity and has been identified as one of the 18 biodiversity hot spots of the world. Agriculture is the main occupation of the people in the northeastern states and shifting cultivation or slash and burn agriculture is the most prevalent form of agricultural practice. About 350,000 people practice shifting cultivation on about 0.4 Mha of unsurveyed land [8].
Shifting cultivation is a wide term covering a number of very different forms of land use, its essential feature being that the land is cleared and agricultural crops are grown for a limited period, ranging from one to over ten years, after which cultivation is abandoned and a new site is chosen for such activities. Anthropogenic pressure on land for shifting cultivation is thus adversely affecting eco-restoration and ecological process of forests. This leads to degradation of land causing soil erosion and finally converting forests into wastelands. This is one of the primary reasons for forest loss in the northeastern states [4].

Under the current context, there is clarity only with respect to the definition of "Deforestation" and uncertainty continues to exist with reference to the other four components namely, forest degradation, forest conservation, sustainable management and enhancement of forest carbon stocks. In the following sections, an assessment of the potential for taking up reducing deforestation and degradation and enhancement of carbon stocks and afforestation in the northeastern states is conducted both at the state as well as district level.

\subsection{Reducing Deforestation}

Deforestation is defined as long-term or permanent conversion of land from forest to non-forest. In the Marrakesh Accord, deforestation is defined as "the direct human-induced conversion of forested land to non-forested land". The Food and Agriculture Organization defines deforestation as "the conversion of forest to another land use or the long-term reduction of the tree canopy cover below the minimum 10\% threshold" [9].

\subsubsection{Estimates of Forest Loss or Deforestation in Northeastern India}

There is a general understanding in India that there is no deforestation and the total forest area is indeed increasing, based on area estimates made by the Forest Survey of India. This is because the gross area trends 
mask any loss or conversion of forests. For estimating loss in forest area or deforestation, the data required include:

- Area of forest remaining forest;

- Area afforested and gaining $10 \%$ tree crown during the period under consideration and;

- Area of actual forest converted to non-forest purposes during the same period.

Such data are not available and here we make an attempt to estimate deforestation or forest loss at the state as well as district level using data published by the Forest Survey of India in the periodic State of Forest Reports.

\subsubsection{Deforestation Estimates at the State Level}

Deforestation is estimated by considering the changes in gross area at the state level, with states indicating positive and negative change in forest area being aggregated separately (Table 3 ) for the northeastern region. The following area changes can be observed during the two successive periods based on changes in area at the state level:

Area changes during 2005-2007 at the state level (Table 3 ) indicate the following:

- Sum of all states with the net gain in forest area or with positive change in forest area is 108.4 ('000) ha.

o Meghalaya, Manipur and Mizoram show an increase in forest area;

0 There is no change in area under forests in the state of Sikkim.
- States with net loss or negative change in forest area when aggregated indicate a loss in forest area of 48.8 ('000) ha (Table 3).

o Four of the eight states show a loss in forest area over the period 2005-2007.

o Maximum loss of forest is in Nagaland followed by Arunachal Pradesh and Tripura and finally Assam.

Thus the net forest loss or deforestation is estimated to be 24,400 ha annually during 2005 to 2007 , even though the gross area estimates for the region shows a net gain of 54,200 ha per annum for the same period. Thus it can be concluded that northeastern states are experiencing net forest loss during the last few years.

\subsubsection{Deforestation Estimates at the District Level}

Estimates of forest loss or deforestation at the district level are done using the district level data available from the Forest Survey of India (FSI) report for the period 2005-2007. All districts showing a negative change in area between the successive forest resource assessments are summed together and similarly those with positive change in area have also been computed (Table 4). The estimates indicate the following.

As can be seen from Table 4, the area under forests has declined in 32 and increased in 30 of the 76 districts in the northeastern states. In the remaining 14 districts, there is no net change in forest area over the period 2005-2007. In Table 5, district wise change in forest area in the 8 northeastern states is presented. As can be seen from Table 5, the net negative change or loss in area is

Table 3. Area under forests and deforestation status $\left(\mathrm{km}^{2}\right)$ for the northeastern states of India.

\begin{tabular}{cccc}
\hline States & Area 2005 (revised) & Area 2007 & Change in area (2005-2007) \\
\hline Nagaland & 1367 & 1346 & -20 \\
Arunachal Pradesh & 6747 & 6735 & -12 \\
Tripura & 817 & 8071 & -10 \\
Assam & 2776 & 2769 & -7 \\
Sikkim & 336 & 336 & 0 \\
Meghalaya & 1721 & 1732 & 12 \\
Manipur & 1695 & 1728 & 33 \\
Mizoram & 1860 & 1924 & 64 \\
& Aggregate change in area gain and loss & & Gain $=+108.4$ \\
\end{tabular}

Table 4. Forest area loss (in ha) estimated at the district level for the northeastern states.

\begin{tabular}{lc}
\hline & $\mathbf{2 0 0 5 - 2 0 0 7}$ \\
\hline Total number of districts in the northeastern states & 76 \\
Number of districts where forest declined & $32^{*}$ \\
Total forest area converted to non-forest, where the canopy cover declined (<10\% canopy cover) & $-71,800$ \\
Number of districts where forest increased & $30^{* *}$ \\
Total forest area increased (>10\% canopy cover) & 131,600 \\
\hline
\end{tabular}

"Not based on the revised estimates, since district data is not available; ${ }^{* *}$ There was no change in forest area in the remaining 14 districts. 
Table 5. Districts with change in area (ha) under forests in the northeast for the period 2005-2007.

\begin{tabular}{|c|c|c|c|c|c|c|c|}
\hline \multirow{2}{*}{ States } & \multirow{2}{*}{ Total no. of districts } & \multicolumn{2}{|c|}{ Districts with positive change } & \multicolumn{2}{|c|}{ Districts with negative change } & \multirow{2}{*}{ Districts with no change } & \multirow{2}{*}{ Net change } \\
\hline & & Number & Area & Number & Area & & \\
\hline Arunachal Pradesh & 13 & 2 & 600 & 9 & 12,500 & 2 & $-11,900$ \\
\hline Assam & 23 & 7 & 3200 & 10 & 9800 & 6 & -6600 \\
\hline Manipur & 9 & 6 & 33,000 & 1 & 200 & 2 & 32,800 \\
\hline Meghalaya & 7 & 5 & 19,800 & 2 & 8200 & - & 11,600 \\
\hline Mizoram & 8 & 7 & 64,400 & 1 & 400 & - & 64,000 \\
\hline Nagaland & 8 & 3 & 10,600 & 5 & 30,700 & - & $-20,100$ \\
\hline Sikkim & 4 & - & - & - & - & 4 & 0 \\
\hline Tripura & 4 & - & - & 4 & 10,000 & - & $-10,000$ \\
\hline
\end{tabular}

highest in the districts of Nagaland, followed by Arunachal Pradesh and Tripura. It is interesting to note that all the 4 districts of Sikkim show no change in area over the period 2005-2007 while all the 4 districts of Tripura show forest loss (negative change in area).

Thus, it can be concluded that among the northeastern states, Nagaland $(20,100$ ha) followed by Arunachal Pradesh (11,900 ha) offer maximum potential for "reducing deforestation" option under REDD and further within Nagaland, maximum potential for this option is in the district of Tuensang, (loss of 12,200 ha and in Arunachal Pradesh, it is Tirap district (5,100 ha). This analysis would help focus efforts on arresting deforestation in states experiencing maximum deforestation, which in total across the 8 northeastern states is 71,800 ha.

\subsubsection{Drivers of Deforestation}

The predominant causes for dwindling forest wealth have been identified as over-exploitation, overgrazing, illegal encroachments, unsustainable practices, forest fires, and an indiscriminate siting of development projects in the forest areas [10]. Area affected by forest fire ranges from 33\% in West Bengal to 99\% in Manipur. However, population pressure is always the underlying cause of overexploitation of the natural resources including forest stock. Possibly, poverty, corruption, weak institutions, and wasteful consumption patterns also combine with the population pressure facilitating depletion and degradation of forest stock having enormous environmental degradation ramifications. In India about 10 million hectares of tribal land stretched across 16 states is under shifting cultivation. Based on satellite image, Forest Survey of India estimates 1.73 million hectares of land as being affected by shifting cultivation. Decrease in forest area due to shifting cultivation is estimated to account for $23 \%$ of the total deforestation in India [11].

In the northeastern states, forests experience an extensive process of forest fragmentation, degradation, and outright deforestation and forest conversion. The management of the forest has suffered in the recent past due to pressure on land, decreasing cycle of shifting cultiva- tion, illegal exploitation of forest for timber and lack of scientific management strategy. Shifting cultivation is an important factor responsible for much of forests being degraded and deforested in the northeastern states, particularly Manipur, Mizoram, Meghalaya and Nagaland. Intensified shifting cultivation, practiced on the hill slopes is impacting forests leading to forest loss or degradation of forests. Increasing number of shifting cultivators has resulted in declined productivity of forest soils, reduced shifting cultivation cycle from $25-30$ to 2 - 3 years, and thus not leaving enough time for the land fertility to be restored.

\subsection{Reducing Forest Degradation}

Forest degradation is a complex process and its drivers may be completely different than those for deforestation. IPCC defined degradation as "direct human-induced activity that leads to a long-term reduction in forest carbon stocks" [12]. Forest degradation as defined and adopted at COP 9 in 2003, is "direct human induced long-term loss (persisting for $\mathrm{X}$ years or more) of at least $\mathrm{Y} \%$ of forest carbon stocks (and forest values) since time (T) and not qualifying as deforestation" [12]. Forest degradation could be considered as reduction of the carbon stock in a natural forest due to the impact of all human induced activities. Inclusion of forest degradation in REDD+ was important [13] to avoid leakage of considerable amounts of forest based emissions (e.g. crown cover of $70 \%$ could be degraded to $15 \%$ and still be classified as forest).

\section{Estimates of Degradation in Northeastern India}

In the absence of data on changes in forest carbon stocks, it may be possible to use forest tree canopy density as an indicator of forest status particularly, from the perspective of forest biomass stocks and degradation $[14,15]$, since data is available for forests with four tree canopy density classes. Any patch of forest losing its tree canopy from higher crown class to lower crown class, could be potentially considered to be subjected to forest 
degradation.

In India, the Forest Survey of India based on monitoring done every two years presents area under forests according to four tree canopy cover densities [4] namely:

$>$ Very dense forest (VDF): All lands having tree cover with canopy density more than $70 \%$;

> Moderately dense forests (MDF): All lands having a tree cover with canopy density between $40 \%-70 \%$;

$>$ Open forests (OF): All lands having a tree cover with canopy density between $10 \%$ and $40 \%$;

$>$ Scrub: All forest lands with poor tree growth mainly small or stunted trees having canopy density less than $10 \%$.

In this section, an attempt has been made to estimate the extent of forest degradation occurring in the northeastern states of India based on the area subjected to decline in crown canopy density between two time periods (2005-2007). An analysis of the forest cover change matrix of the FSI [4] for the northeastern states (Table 6) indicates that there is an overall increase in forest area over the assessment period 2005 to 2007, considering all the 8 northeastern states. But, there is a net increase in forest area only in 3 of the 8 states of the northeast, namely Manipur, Meghalaya and Mizoram. In the other states, there is a net decrease in forest area and ranges from 20.1 ('000) ha in Nagaland to 6.6 ('000) ha in Assam.

When we further analyze the change in area under the different forest density classes, there is a net increase in very dense and open forest cover across the 8 states and a net decrease in the moderately dense forests. This pattern varies across the states and a net increase in very dense forests is recorded only in Manipur and Meghalaya (overall 8.8 ('000) ha) while in all other states, there is a net overall decrease of about 1.2 ('000) ha. In the moderately dense category, there is a net loss in forest area in all the states and it is highest in Nagaland and least in Meghalaya. Correspondingly, there is maximum increase in area under the open forests in all the states except
Arunachal Pradesh, Nagaland and Tripura, with an overall net increase of 112 ('000) ha across the 8 states.

It can be concluded that based on the 2005-2007 data published by FSI, significant scale forest degradation is occurring in the northeastern states with $599 \mathrm{sq} \mathrm{km}$ of moderately dense forests declining to lower canopy density classes. This area could be considered as potential for "reducing degradation" option under REDD.

\subsection{Forest Conservation}

Forest conservation encompasses those measures concerned with the protection and preservation of forest lands and resources. Forests designated for wildlife or habitat protection, usually found within national parks and other protected areas are deemed as "Conservation Areas". The term forest conservation under the UNFCCC discussions and negotiations is however not clearly defined. It can be understood however that forest conservation is a means to reduce emissions from forests and refers to a system in which forest carbon stocks are conserved or maintained (not enhanced). It could involve maintenance of area under existing forests to maintain the forest area with high carbon stocks. Forest conservation, in addition to maintaining carbon, provides other environmental services, such as preserving biodiversity. The best example of forest conservation activity is formation of Protected Areas (PA), where the main goal is to conserve and maintain the forest area with its biodiversity intact, by reducing all disturbances or extraction of forest products.

In India, about 15.87 Mha is under PA. The area under PA management is increasing in India and the same is the case in the northeastern states. Currently, 680,000 ha is under National Parks (NP) and 1,058,000 ha is under Wild Life Sanctuaries (WLS) in the northeastern states (Table 7). Additionally it is proposed to demarcate 373,000 ha as NPs and 492,000 ha as WLS in the northeastern states.

Table 6. Change in forest area ('000 ha) under different density classes for the assessment period 2005 to 2007 in northeast India.

\begin{tabular}{|c|c|c|c|c|c|c|c|c|c|c|c|c|}
\hline \multirow{2}{*}{ States } & \multicolumn{2}{|c|}{ VDF } & \multicolumn{2}{|c|}{ MDF } & \multicolumn{2}{|c|}{$\mathbf{O}$} & \multicolumn{2}{|c|}{ Total } & \multicolumn{4}{|c|}{ Change } \\
\hline & 2005 & 2007 & 2005 & 2007 & 2005 & 2007 & 2005 & 2007 & VDF & MDF & $\mathbf{O}$ & Total \\
\hline Arunachal Pradesh & 2086 & 2086 & 3163 & 3156 & 1498 & 1494 & 6747 & 6735 & -0.1 & -7.6 & -4.2 & -11.9 \\
\hline Assam & 146 & 146 & 1165 & 1156 & 1464 & 1467 & 2776 & 2769 & -0.3 & -9.5 & 3.2 & -6.6 \\
\hline Manipur & 69 & 70 & 552 & 547 & 1074 & 1111 & 1695 & 1728 & 1.2 & -4.8 & 36.4 & 32.8 \\
\hline Meghalaya & 33 & 41 & 953 & 950 & 734 & 741 & 1721 & 1732 & 7.6 & -2.6 & 6.6 & 11.6 \\
\hline Mizoram & 13 & 13 & 638 & 625 & 1208 & 1286 & 1860 & 1924 & 0.0 & -13.3 & 77.3 & 64.0 \\
\hline Nagaland & 128 & 127 & 507 & 490 & 731 & 729 & 1367 & 1346 & -0.6 & -17.5 & -2.0 & -20.1 \\
\hline Tripura & 11 & 11 & 482 & 477 & 324 & 319 & 817 & 807 & -0.2 & -4.6 & -5.2 & -10.0 \\
\hline TOTAL & 2487 & 2495 & 7461 & 7401 & 7035 & 7147 & 16,983 & 17,042 & 7.6 & -59.9 & 112.1 & 59.8 \\
\hline
\end{tabular}

Note: In Sikkim, there is no change in forest area between 2005-2007 and therefore not included in the table; Source: FSI. 
Table 7. Existing and proposed area (' 000 ha) under Protected Areas in the northeastern states.

\begin{tabular}{|c|c|c|c|c|c|c|c|c|}
\hline \multirow{2}{*}{ State } & \multicolumn{4}{|c|}{ Existing } & \multicolumn{4}{|c|}{ Proposed } \\
\hline & No. of NPs & Area ('000 ha) & No. of WLS & Area ('000 ha) & No. of NPs & Area ('000 ha) & No. of WLS & Area ('000 ha) \\
\hline Arunachal Pradesh & 2 & 229 & 11 & 761 & 6 & 232 & 7 & 99 \\
\hline Assam & 5 & 197 & 15 & 88 & 2 & 53 & 10 & 163 \\
\hline Manipur & 1 & 4 & 3 & 39 & 2 & 24 & 10 & 102 \\
\hline Meghalaya & 2 & 27 & 3 & 3 & 2 & 41 & 4 & 66 \\
\hline Mizoram & 2 & 25 & 4 & 77 & 1 & 24 & 3 & 19 \\
\hline Nagaland & 1 & 20 & 3 & 2 & 0 & 0 & 6 & 43.5 \\
\hline Sikkim & 1 & 178 & 5 & 27 & - & - & - & - \\
\hline Tripura & 0 & 0 & 4 & 60 & - & - & - & - \\
\hline Total & 14 & 680 & 48 & 1058 & 13 & 373 & 40 & 492 \\
\hline
\end{tabular}

Since in the PAs, extraction is regulated or banned and forest vegetation and biodiversity and in turn forest carbon stock is potentially conserved, the area could be considered for forest conservation activities under the REDD. In the case of north east India, there are a number of forest dwelling tribal communities, such as in the state Arunachal Pradesh, which have played a significant role in conserving the virgin forests over these years owing to their strict traditional customary laws and clan regulations. Village level workshops held in the past have stressed upon the fact that the role of the traditional people for conserving their native forest, must be recognized under a REDD + mechanism through paid incentives and "community virgin forests" (CVFs) need to be established as "community reserve forests" (CRFs).

\subsection{Enhancement of Carbon Stocks}

Carbon stock enhancement involves restoring carbon stocks in degraded forests, or creating forests where none currently exist and approaches include afforestation, reforestation, restoration through natural regeneration, assisted natural regeneration or planting, rehabilitation, or forest landscape restoration [16]. Under this component of REDD + mechanism, forest carbon stocks could be enhanced due to improved forest management, longer rotation, denser stocking, forest restoration and rehabilitation of wastelands through afforestation.

The potential locations for carbon stock enhancement are dispersed in the various districts of the northeastern states and afforestation and forest restoration programmes could be implemented in these districts. Districts with large area under wastelands could be considered as potential locations for carbon stock enhancement. Districts with wastelands more than 100,000 ha are considered for this analysis and the wasteland categories considered include land with dense and open scrub, abandoned shifting cultivation areas and under-utilized or degraded categories. The total area for this option is thus $2,567,507$ ha.

\section{MITIGATION POTENTIAL ESTIMATES}

Several models are available for estimating the mitigation potential. Some of the widely adopted models include COMAP, GCOMAP, $\mathrm{CO}_{2} \mathrm{Fix}$, Roth $\mathrm{C}$ and CENTURY [17]. The mitigation potential of different activities or options proposed is estimated using COMAP, taking into consideration the area and phasing of the various activities. The GCOMAP model has been used by Sathaye et al. [18], Ravindranath et al. [19] and Ravindranath et al. [20] for estimating the mitigation potential at the global and national level. The mitigation potential estimated is determined by the following:

- Area brought under afforestation/protection/management;

- Species-mix and density;

- Carbon pools (aboveground and belowground biomass, soil organic carbon and dead organic matter) considered;

- Rates of change in the carbon pools: Mean Annual Increments;

- Transfer and dynamics of different carbon pools;

- Harvest and extraction of timber, fuelwood etc;

- Initial stock of different carbon pools;

- Phasing of the activity and area planted in different years.

\subsection{The Model}

The COMAP or Comprehensive Mitigation Analysis Process is a set of models developed by Lawrence Berkeley National Laboratory aimed at estimating the quantity of carbon sequestration achieved for a given year or over a period of years as well as the financial implications and cost effectiveness of forestry mitigation projects. These models have been extensively used for assessing mitigation potential [21-24]. The COMAP uses linear growth rates for biomass and soil carbon increments. Data input for the model includes changes in area 
under forests and degraded lands under baseline scenario, area proposed for afforestation or reforestation under mitigation scenario, carbon densities of vegetation and soil, rates of carbon sequestration, costs and benefits. The model estimates the following under baseline and mitigation scenario:

- Changes in C stock (biomass and soil) annually and cumulatively.

o tC/ha and for the total area.

- Cost-effectiveness indicators such as.

o Cost in $\$ / \mathrm{tC}$ sequestered.

o Cost in $\$ /$ ha.

- $\mathrm{NPV}$ (net present value) in $\$ / \mathrm{tC}$ sequestered or emission avoided.

Carbon pools selected: Four of the five carbon pools are assessed using COMAP, including aboveground biomass (AGB), belowground biomass (BGB, through an expansion factor), litter, and soil organic carbon (SOC); dead wood (DW) is not included.

Area data: The potential area for the four REDD+ options was discussed in Section 3.

Growth rates: An attempt was made to obtain the data required for COMAP. Several studies and reports were reviewed and biomass and soil carbon data was compiled, but availability of data on area, biomass, soil carbon, and financial inputs is limited. Given this limitation, the growth rates used for estimation of mitigation potential of the Greening India Mission is used [25].

\subsection{Mitigation Potential Estimates}

The mitigation potential for the four options was estimated using COMAP model for the northeastern states. The growth rates for aboveground biomass and soil organic carbon were obtained from literature [25] and belowground biomass is computed using the IPCC default value of 0.26 .

The incremental annual mitigation potential of the four REDD + activities or options was estimated to be 29 $\mathrm{MtCO}_{2}$ for 2030, with a cumulative mitigation potential of $487 \mathrm{MtCO}_{2}$ for the period 2010 to 2030 and 1012
$\mathrm{MtCO}_{2}$ for the period 2010 to 2050 (Table 8). These estimates exclude any emissions resulting from harvest and disturbance.

\section{CONCLUSIONS}

Over the last couple of decades, India has been implementing various policies designed to reduce deforestation and degradation, with mixed success. There have also been advances in community forest management and protected area management, the elimination of perverse incentives to clear forests. India has been implementing one of the world's largest afforestation programmes to meet its biomass requirement (fuelwood, timber and non-timber products) and for forest conservation purposes. India has also set a goal of covering about one-third of the geographic area under forests, compared to less than $20 \%$ area currently under forests. This goal is still higher in the case of hilly states wherein as per the National Forest Policy 1988, 2/3 of the geographic area is to be under forest/tree cover. Further, the Government of India has formulated a large Greening India Mission aimed at mitigation and adaptation, with the goal of enhancing ecosystem services such as carbon sequestration and storage, biodiversity conservation and provision of biomass and NTFPs. The Mission aims at responding to climate change by combination of adaptation and mitigation measures which would aim at;

- Enhancing carbon sinks in sustainably managed forests and other ecosystems;

- Adaptation of vulnerable species/ecosystems to the changing climate; and

- Adaptation of forest dependent communities.

- Thus many states including the northeastern states are proposing mitigation and adaptation projects under State Action Plans for addressing climate change impacts on forest ecosystems as well as to mitigate the climate change through enhancing the carbon sinks. The Mission is further significant in the context of northeast India as the percentage of forest dependent people is quite large.

Table 8. Incremental and cumulative mitigation potential $\left(\mathrm{MtCO}_{2}\right)$.

\begin{tabular}{ccccc}
\hline Options & Area (Mha) & $\begin{array}{c}\text { Incremental annual mitigation } \\
\text { potential } \mathbf{2 0 3 0}\left(\mathbf{M t C O}_{\mathbf{2}}\right)\end{array}$ & \multicolumn{2}{c}{$\begin{array}{c}\text { Incremental cumulative mitigation } \\
\text { potential (MtCO}\end{array}$} \\
\cline { 3 - 5 } & & 1.1 & $\mathbf{2 0 1 0 - 2 0 3 0}$ & $\mathbf{2 0 1 0 - 2 0 5 0}$ \\
\hline Reducing deforestation & 0.06 & 0.7 & 17.7 & 37.6 \\
Reducing degradation & 0.07 & 7.9 & 10.5 & 22.3 \\
Forest conservation & 0.87 & 19.5 & 146.2 & 288.4 \\
Carbon stock enhancement & 2.57 & 29.2 & 312.6 & 664.3 \\
Total & 3.56 & 487.0 & 1012.7 \\
\hline
\end{tabular}

Notes: Carbon pools considered: Aboveground and belowground biomass, soil and litter pools; Area to be planted: Phased equally over 10 years, starting 2012. Growth rates: Reducing deforestation: $1.51 \mathrm{t} / \mathrm{ha} / \mathrm{yr}$; Reducing degradation: $3.56 \mathrm{t} / \mathrm{ha} / \mathrm{yr}$; Forest conservation: $1.5 \mathrm{t} / \mathrm{ha} / \mathrm{yr}$; Enhancement of carbon stocks: 0.84 $\mathrm{t} / \mathrm{ha} / \mathrm{yr}$. BGB growth rate: Computed using the IPCC default value of 0.26 of AGB; Litter (micro and macro litter) growth rate: $0.5 \mathrm{t} /$ ha/yr. SOC growth rate: $0.22 \mathrm{tC} / \mathrm{ha} / \mathrm{yr}$. 
An analysis and estimation by the World Resources Institute [26] indicate emissions gap in meeting targets while estimates by den Elzen et al. [27] show that by reducing emissions from deforestation by $50 \%$ below 1995 levels, the global community could possibly close this emissions gap. Further, the Eliasch Review [28] indicates that the global cost of climate change caused by deforestation could reach $\$ 1$ trillion a year by 2100 and including REDD, and an additional action on sustainable management in a well designed carbon trading system could provide the finance and incentives to reduce deforestation rates up to $75 \%$ in 2030 , and the addition of afforestation, reforestation and restoration would make forest sector carbon neutral.

This study has estimated the potential area available for different options under REDD + as well the mitigation potential, overcoming limitations of existing studies or a lack of them. There are however uncertainty in these estimates, which stem from use of one growth rate for an activity, not considering regional variations in physiography and climate. This is because there is a lack of growth rate data available and the uncertainty could be reduced by generating reliable, disaggregated estimates of the carbon stock gain by mitigation option, considering varied growth rates.

REDD+ provides increasing incentives for forest protection and although designed to limit harmful climate change, it could provide collateral benefits such as conservation of biodiversity. This is however dependent on the extent to which emissions reductions and biodiversity conservation can be achieved in the same places. Yet without specific provisions for biodiversity, REDD is likely to protect forests that are most cost-effective for reducing carbon emissions [29]. O. Venter et al. [30] have demonstrated that prudent targeting of REDD funds can double biodiversity benefits while incurring only a small reduction ( $4 \%$ to $8 \%$ ) in carbon benefits. There are however challenges in developing equitable benefit sharing mechanisms at different scales and would require adoption of pro-poor approach that is central to development of community-based approaches to forest management [31].

Some of the essential pre-requisites for successful implementation of REDD+ mechanism, in addition to clarity on methodological issues that is under development at the global level are:

- Ensure natural forests, particularly old growth forests are safeguarded and biodiversity is not threatened;

- Indigenous forest dwellers and forest dependent local communities are an integral part of the entire process and have sufficient incentives to ensure projects are successful;

- Effective mechanisms are developed to quantify reductions of emissions and assess the correct monetary value of a forest;

- Sufficient funds, irrespective of whether it comes from national or international source are made available;

- Each stage of a REDD project, from approval to completion is transparent, and there is accountability.

Thus, building of a national REDD-plus system presents a huge and unprecedented undertaking for forest protection, management, restoration and establishment, in addition to the technical challenges of establishing national architecture to accurately measure, monitor, and report national forest carbon stocks, and emissions and removals [32]. Developing countries such as India are starting from a difficult position as, till date, national inventories were never intended for the purpose of forest carbon accounting. However, the introduction of REDD will open opportunities to reverse deforestation trends and capture forest carbon values in regions like the northeast India, wherein deforestation and forest degradation along with protection of the rights of indigenous people and traditional communities are issues of concern.

\section{REFERENCES}

[1] Laurance, W. F. (2008) Can carbon trading save vanishing forests? BioScience, 58, 286-287. doi:10.1641/B580402

[2] Metz, B., Davidson, O.R., Bosch, P.R., Dave, R. and Meyer, L.A. (2007) Climate change 2007: Mitigation. Contribution of working group III to the fourth assessment report of the intergovernmental panel on climate change. Cambridge University Press, Cambridge and New York.

[3] http://www.indiastat.com

[4] FSI (2009) The state of forest report, forest survey of India. Ministry of Environment and Forests, Government of India, New Delhi.

[5] Barik, S.K., Darlong, V.T., Palit, S., Poffenberger, M., Roy, I., Tiwari, B.K. and Upadhyay, S. (2005) Community forestry in Northeast India: Recommendations for action. Community Forestry International, Santa Barbara.

[6] Roy, P.S. and Joshi, P.K. (2002) Forest cover and assessment in North East India: Issues and policies. Indian Institute of Remote Sensing (NRSA), Dehradun. http://www.gisdevelopment.net/magazine/gisdev/2002/

[7] Banerjea, P. (2005) Northeast of India - Cradle of Naturenomics TM.

[8] Jeeva, S.R.D.N., Laloo, R.R. and Mishra, B.P. (2006) Traditional agricultural practices in Meghalaya, North East India. Indian Journal of Traditional Knowledge, 5, 7-18.

[9] Angelsen, A., Brown, S., Loisel, C., Peskett, L., Streck, L. and Zarin, D. (2009) Reducing Emissions from Deforestation and Forest Degradation (REDD): An options assessment report. www.REDD-OAR.org

[10] GoI (1999) Economic survey, 1998-99. Economic Division, Ministry of Finance, Government of India, New Delhi. 
[11] Manhas, R.K., Negi, J.D.S., Kumar, R. and Chauhan, P.S. (2006) Temporal Assessment of Growing Stock, Biomass and Carbon Stock of Indian Forests. Climatic Change, 74, 191-221.

[12] Penman, J., Gytarsky, M., Krug, T., Kruger, D., Pipatti, R., Buendia, L., Miwa, K., Ngara, T., Tanabe, K. and Wagner, F., Eds. (2003) Definitions and methodological options to inventory emissions from direct human-induced degradation of forests and devegetation of other vegetation types. Intergovernmental Panel on Climate Change, Kanagawa.

[13] Murdiyarso, D., Skutsch, M., Guariguata, M., Kanninen, M., Luttrell, C., Verweij, P. and Stella, O. (2008) Measuring and monitoring forest degradation for REDD: Implications of country circumstances. CIFOR Infobriefs, 16.

[14] Bajracharya, S. (2008) Community carbon forestry: Remote sensing of forest carbon and forest degradation in Nepal. Master Thesis of Science in Geo-information Science and Earth Observation for Environmental Modeling and Management, International Institute for Geo-Information Science and Earth Observation, Enschede.

[15] Rikimaru, A., Roy, P.S. and Miyatake, S. (2002) Tropical forest cover density mapping. Tropical Ecology, 43, 3947.

[16] Miles, L. (2010) Implications of the REDD negotiations for forest restoration: Version 2. UNEP World Conservation Monitoring Centre, Cambridge.

[17] Ravindranath, N.H and Ostwald, M. (2008) Carbon inventory methods-Handbook for greenhouse gas inventory, carbon mitigation and roundwood production projects. In: Global Change Research, Springer Verlag, Berlin, 304.

[18] Sathaye, J., Makundi, W.R., Andrasko, K., Boer, R., Ravindranath, N.H., Sudha, P., Rao, S., Lasco, R., Pulhin, F., Masera, O., Ceron, A., Ordonez, J., Deying, X., Zhang, X. and Zuomin, S. (2001) Carbon Mitigation Potential and Costs of Forestry Options in Brazil, China, India, Indonesia, Mexico, The Philippines, and Tanzania. Mitigation and Adaptation Strategies for Climate Change, 6, 185-211.

[19] Ravindranath, N.H., Sudha, P. and Rao, S. (2001) Forestry for sustainable biomass production and carbon sequestration in India. Mitigation and Adaptation Strategies for Global Change, 6, 233-256. doi:10.1023/A:1013331220083

[20] Ravindranath, N.H., Chaturvedi, R.K. and Murthy, I.K. (2008) Forest conservation, afforestation and reforestation in India: Implications for forest carbon stocks. Current Science, 95, 216-222.

[21] Sathaye, J. and Ravindranath, N.H. (1998) Climate change mitigation in the energy and forest sectors of developing countries. Annual Review of Energy and Environment, 23, 387-437. doi:10.1146/annurev.energy.23.1.387

[22] Ravindranath, N.H. and Sathaye, J. (2002) Climate change and developing countries. Kluwer Academic, Dordrecht.

[23] Murthy, I.K., Hegde, G.T., Sudha, P. and Ravindranath, N.H. (2006) Methodological issues in developing a community forestry mitigation project in Mancherial forest division of Andhra Pradesh, India. Environmental Science and Policy, 9, 525-537. doi:10.1016/j.envsci.2006.03.008

[24] Ravindranath, N.H., Murthy, I.K., Chaturvedi, R.K., Andrasko, K. and Sathaye, J.A. (2007) Carbon price-driven forestry mitigation in India by land classification. Mitigation and Adaptation Strategies for Global Change, 12, 1027-1050. doi:10.1007/s11027-006-9063-4

[25] Ravindranath, N.H. and Murthy, I.K. (2010) Greening India mission. Current Science, 99, 444-449.

[26] Levin, K. and Bradley, R. (2010) Comparability of annex I emission reduction pledges. World Resources Institute, Washington DC.

[27] Den Elzen, M.G.J., Hof, A.F., Mendoza Beltran, M.A., Roelfsema, M., Van Ruijven, B.J., Van Vliet, J., Van Vuuren, D.P., Höhne, N. and Moltmann, S. (2010) Evaluation of the Copenhagen accord: Chances and risks for the $2^{\circ} \mathrm{C}$ climate goal. Netherlands Environmental Assessment Agency (PBL), Hague.

http://www.usclimatenetwork.org/resource-database/ecof ys-evaluation-of-thecopenhagen-accord-chances-and-risk s-for-the-2b0c-climate-goal

[28] Eliasch, J., (2008) Climate change: Financing global forests: The Eliasch review. Earthscan, London.

[29] Miles, L. and Kapos, V. (2008) Reducing greenhouse gas emissions from deforestation and forest degradation: Global land-use implications. Science, 320, 1454-1455. doi:10.1126/science. 1155358

[30] Venter, O., Meijaard E., Possingham, H. et al. (2009) Carbon payments as a safeguard for threatened tropical mammals. Conservation Letters, 2, 123-129.

http://www.occ.gov.uk/activities/eliasch/Full_report_elias ch review(1).pdf

[31] CARE (undated) CARE makes carbon finance work for poor and marginalised people. CARE \& Climate Change. http://www.careclimatechange.org/files/carbon/CarbonFi nance09.pdf

[32] IGES (2010) Developing National REDD-plus Systems: Progress challenges and ways forward. Indonesia and VietNam country studies. Institute for Global Environmental Strategies (IGES), Kanagawa. 